\title{
Acute and Subchronic Oral Toxicity Studies of an Ethanol/Water Extract of Euphorbia scordifolia Jacq (Euphorbiaceae) in Mice and in Rats
}

\author{
Michel Archange Tagne Fokam ${ }^{1, a^{*}}$, Paul Aimé Noubissi ${ }^{2, b}$, René Kamgang ${ }^{3,4, c}$ \\ ${ }^{1}$ Department of Biological Science, Faculty of Science, University of Ngaoundéré, Cameroon \\ ${ }^{2}$ Department of Zoology and Animal Physiology, Faculty of Science, University of Buea, Cameroon \\ ${ }^{3}$ Animal Physiology Laboratory, Faculty of Science, University of Yaoundé I, Cameroon \\ ${ }^{4}$ Laboratory of Endocrinology and Radioisotopes, Institute of Medical Research and Medicinal \\ Plants Studies (IMPM), Yaoundé, Cameroon
}

afmarchange@gmail.com, bnoubiaime@yahoo.fr, gemskruy@yahoo.fr

Keywords: Euphorbia scordifolia, ethanol/water extract, toxicity, mice, rats.

\begin{abstract}
Euphorbia scordifolia is used in Cameroon as galactagogue and in the treatment of gastrointestinal disorders. This work was undertaken to evaluate the acute and subchronic toxicities of ethanol/water extract of Euphorbia scordifolia (EWEs). Acute toxicity study was carried out by oral administration of 1, 2, 3, 4 and $5 \mathrm{~g} / \mathrm{kg}$ body weight of EWEs to mice in the respective groups. Subchronic toxicity study was conducted by oral administration of the extract at daily doses of 50, 75 and $100 \mathrm{mg} / \mathrm{kg}$ body weight to another group of rats for 28 days, while rats in the control group received $10 \mathrm{~mL} / \mathrm{kg}$ body weight of distilled water. Following the 28 -day treatment, the rats were sacrificed for hematological, biochemical and histopathology studies. In the acute toxicity study, EWEs was found to be non-toxic at a dose of $5000 \mathrm{mg} / \mathrm{kg}$ body weight. The subchronic treatment with EWEs did not alter either the body weight gain or the food and water consumption. Biochemical analysis did not show any significant differences in any of the parameters examined in males or females. Hematological analysis showed a significant decrease $(\mathrm{P}<0.01)$ in white blood cells and red blood cells in males treated with $100 \mathrm{mg} / \mathrm{kg}$ bw and a significant $(\mathrm{P}<0.01)$ decrease in hemoglobin and hemoglobin hematocrit in all treated females. Necropsy and histopathological examination revealed some slight hepatic necrosis with the dose $100 \mathrm{mg} / \mathrm{kg}$ bw. It would be necessary to use the ethanol/water extract for short periods $(<4$ weeks). Thus, the plant, at least its ethanol/water extract, could be considered with a wide margin of safety for short-term oral use.
\end{abstract}

\section{Introduction}

The use of plant and animal-derived toxins by humans has been reported throughout history [1]. Euphorbia scordifolia Jacq (Euphorbiaceae) is an annual sub-wood, up to $40 \mathrm{~cm}$ high [2], containing white latex. The leaves $0.4-1.7 \times 0.3-1 \mathrm{~cm}$ are opposite and couplets have elongated limbs, long 8 to $15 \mathrm{~mm}$ and wide 8 to $12 \mathrm{~mm}$. E. scordifolia is commonly found in arid environments, on dry and sandy soils. E. scordifolia, commonly called "breast milk", "Fragile 1500" in Batié (West Region of Cameroon), "tanut" in Hassaniya (Mauritania) [3] is used as painkillers and lactation stimulants and in traditional medicine against diarrhea, dysentery, diabetes and indigestion [4]. In Nigeria a plant-decoction is applied to women's breasts as a galactogogue, on aching teeth, for bites of the tsetse fly and to treat dysentery [5]. The plant is grazed by sheep and goats in Mauritania, and the cattle, sheep and goats in Senegal [3]. Doses 50 and $75 \mathrm{mg} / \mathrm{kg}$ bw of Euphorbia scordifolia (EWEs) ethanol/water extract showed significant antidiarrheal activities in Shigella dysenteriae type 1-induced diarrhea in rats during six days of treatment [6]. The usability of EWEs in human diarrheal/dysentery indications could be considerable, but the toxicological study on EWEs is limitation. The present study therefore aims at investigating the acute and subchronic oral toxicity studies of an EWEs in mice and in rat. 


\section{Materials and Methods}

\section{Plant Material}

For ethanol/water extract of Euphorbia scordifolia Jacq (EWEs), fresh E. scordifolia plants were harvested in September in Batié borough (West Region, Cameroon) and identified by the National Herbarium, Yaoundé-Cameroon, where a sample is well preserved under registration $\mathrm{Nr}$ 20631/SFR Cam. The whole plant was washed with water, dried in the shade then ground manually. $1000 \mathrm{~g}$ of powder were macerated in ethanol-water $(1: 3)(5 \mathrm{~L})$ for 72 hours in a percolator. After percolation and concentration of the filtrate, we obtained 55.8g (5.6\%) of dark EWEs. This extract was dissolved in sterile distilled water. The volume of oral administration was $10 \mathrm{~mL} / \mathrm{kg}$ body weight for each experimental animal.

\section{Preliminary Phytochemical Screening Test}

Screening of the phytochemical properties of the ethanol/water extract of E. scordifolia was done using the following chemicals and reagents[7]: alkaloids with Mayer and freshly prepared Dragendoff's reagents, terpenoids and sterols (Liebermann-Burchard test), phenols and tannins $\left[\mathrm{FeCl}_{3}\right.$ and $\mathrm{K}_{3} \mathrm{Fe}(\mathrm{CN})_{6}$ ], flavonoids with Shinoda test [magnesium turnings and $\mathrm{K}_{3} \mathrm{Fe}(\mathrm{CN})_{6}$, polysaccharides with Molish test (with $\alpha$-naphtol and $\mathrm{H}_{2} \mathrm{SO}_{4}$ ), saponins (frothing test), phlobotannins $\left(\mathrm{FeCl}_{3}\right.$ and $\left.\mathrm{HCl}\right)$, anthraquinones $\left(\mathrm{NH}_{4} \mathrm{OH}\right)$ and lipids with filter paper. Each test was qualitatively expressed as negative $(-)$ or positive $(+)$.

\section{Experimental Animals}

Adult male and female Wistar rats (weighing 178-200 and 144-162 g, respectively), adult male and female mice (weighing 20-30 g) were obtained from the Animal house of Institute for Medical Research and Medicinal Plants Studies (Yaoundé city, Cameroon). They were maintained at room temperature with alternating day and night. The feed consisted of a mixture of corn flour $(60 \%)$, wheat flour (10\%), fish meal (12\%), soybean meal (15\%), and oil palm (3\%) [8]. Drinking water was tap water containing a vitamin B complex. Animals were acclimated for 7 days prior to experimentation. During the experiment, each animal was housed individually in a metabolic cage. Animal housing and in vivo experiments were done according to the guidelines of the European Union on Animal Care (CEE Council 86/609)[9] that was adopted by the Institutional Committee of the Ministry of Scientific Research and Innovation of Cameroon.

\section{Acute Oral Toxicity}

The acute toxicity of the extract was evaluated in 60 normal albino mice separated into six groups of ten mice each (five males and five females). Each group was fasted for $12 \mathrm{~h}$, after which time they were twice treated orally with one of an increasing dose of the extract: $0,1,2,3,4$ or $5 \mathrm{~g} / \mathrm{kg}$. The treated mice were deprived of food and water for two hours. Signs and apparent symptoms of intoxication (lethargy, jerkiness, sensitiveness to noise and touch, death and stools quantity and quality) are observed and recorded after 2 hours, 48 hours and after 7 days [10-13].

\section{Subchronic Oral Toxicity}

Forty animals were randomly divided into four groups containing ten (10) rats each (5 females and 5 males). EWEs dissolved in distilled water was administered to groups of rats at the doses of $0,50,75$ and $100 \mathrm{mg} / \mathrm{kg}$ body weight (bw) by gavage of $1 \mathrm{~mL} / 100 \mathrm{~g}$ bw for 4 weeks. Each animal was housed in a metabolic cage to individually evaluate different parameters. The animals were observed for signs of toxicity and mortality throughout the experimental period. The weight of each rat was recorded at weekly intervals throughout the course of the study. Food and water consumption, fecal and urinary voiding were evaluated daily for 4 weeks of treatment [14].

After 4 weeks of treatment, animals were weighed and sacrificed by decapitation and their blood collected a part in EDTA tubes for hematology (white blood cell, red blood cells, hematocrit, and hemoglobin) and the other part in dry hemolysis tubes for biochemical assays creatinine, alanine aminotransferase and of the total protein. The blood was centrifuged at $4000 \times \mathrm{g}$ at $4{ }^{\circ} \mathrm{C}$ for 
30 min to obtain serum (stored at $-20^{\circ} \mathrm{C}$ until biochemical analysis). The organs (kidneys, liver, lungs, heart and spleen) were removed, freed of any fatty material, weighed and the relative organ weights (ROW) determined by the formulae:

$$
\mathrm{ROW}=\frac{\mathrm{ow}}{\mathrm{bw}} \times 100,
$$

where, ow $=$ organ weight and $\mathrm{bw}=$ body weight.

Kidneys, liver and spleen samples were fixed in 10\% formalin for histopathological examination.

\section{Hematological Analysis}

Red blood cells (RBCs), white blood cells (WBCs), and platelet cells (PCs) were counted by manual method [6] using standard light microscope (MOTIC 1820 LED: SM7432-MC1STRPIWFM). The Hematocrit (Ht) was determined using a micro hematocrit tube. The Hemoglobin $(\mathrm{Hb})$ concentration was measured by spectrophotometer method. The blood was diluted in Drabking solution (1/250) and the absorbance was evaluated at $510 \mathrm{~nm}$. Mean corpuscular volume (MCV), mean corpuscular hemoglobin $(\mathrm{MCH})$ and mean corpuscular hemoglobin concentration (MCHC) were determined respectively by the formulae:

$$
\begin{aligned}
& M C V=\frac{\mathrm{Ht}}{\mathrm{RBC}} \times 10, \\
& M C H=\frac{\mathrm{Hb}}{\mathrm{RBC}} \times 10, \\
& M C H C=\frac{\mathrm{Hb}}{\mathrm{Ht}} \times 10 .
\end{aligned}
$$

\section{Biochemical Analysis}

For biochemical analysis, following parameters were determined: protein, creatinine and alanine aminotransferase (ALT). Total protein were assayed by the colorimetric Biuret method [15]. Creatinine rate was determined by the kinetic method using the kit "linear chemicals" in blood and in urine. Alanine aminotransferase rate was determined by the kinetic method using the kit "Fortress diagnostics, ALT (GPT)".

\section{Histopathological Analysis}

Histopathological investigation was done according to methods described in literature [16]. In addition to the organs mentioned above, the kidneys, liver and spleen samples excised from all the experimental rats were fixed in $10 \%$ buffered formalin in labeled bottles, and processed for histological examination. Tissues embedded in paraffin wax were sectioned $2 \mu \mathrm{m}$ thick, stained with haematoxylin and eosin, mounted on glass slides and examined under a standard light microscope (MOTIC 1820 LED: SM7432-MC1ST-RPIWFM).

\section{Statistical Analysis}

Data were expressed as mean \pm standard error of mean $(\mathrm{X} \pm$ S.E.M). Data were analyzed by one-way ANOVA followed by Dunnett's t-test and Tukey test using computerized Graph Pad InStat 3.05 version (Graph Pad software, U.S.A.).

\section{Results}

\section{Phytochemistry Properties}

Preliminary phytochemical screening showed the presence of phenols, triterpenoids, anthocyanidins, anthraquinones, coumarins, saponins in ethanol/water extract of E. scordifolia (Table 1). 
Table 1. Phytochemical screening of ethanol/water extract of E. scordifolia (EWEs).

\begin{tabular}{lc}
\hline Research compounds & Reaction \\
\hline Galli tannin & - \\
Catecho tannin & - \\
Triterpenoids & + \\
Sterol & - \\
Phenol & + \\
Alkaloids & - \\
Anthocyanidins & + \\
Anthraquinones & + \\
Coumarins & + \\
Flavonoïds & - \\
Saponins & + \\
Lipids & + \\
Volatile oils & + \\
\hline (+): positive; (-): negative &
\end{tabular}

\section{Acute Toxicity}

The results obtained from the acute oral toxicity study showed that ethanol/water extract of $E$. scordifolia demonstrated high safety margin when the animals tolerated up to $5000 \mathrm{mg} / \mathrm{kg}$ body weight of the extracts orally. Even at this high dose, there were no gross behavioral changes.

\section{Subchronic Toxicity}

\section{Effect of Ethanol/Water Extract of E. scordifolia on General Behavior}

In the subchronic toxicity study, both the male and female rats treated with ethanol/water extract of E. scordifolia did not exhibit symptoms of toxicity.

\section{Effect of Ethanol/Water Extract of E. scordifolia on Variation in Mean Body Weight}

The variation in mean body weight with period of treatment has changed little in treated animals remained lower than the control group. In all treated male rats with ethanol/water extract of E. scordifolia, the weight variation decreased significantly $(\mathrm{P}<0.01)$ from the second week of treatment compared to the control group (Fig. 1A). The weight variation was relatively low in all females treated with ethanol/water extract of E. scordifolia compared to the control group during treatment (Fig. 1B).

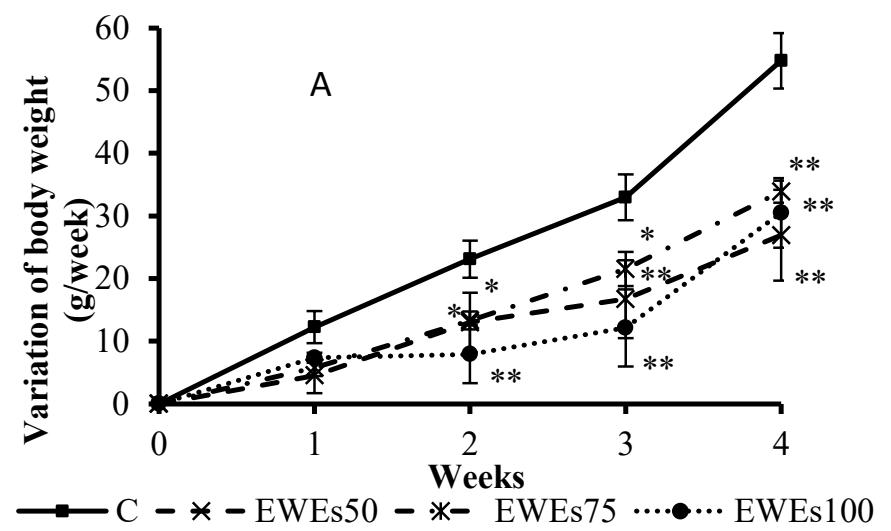




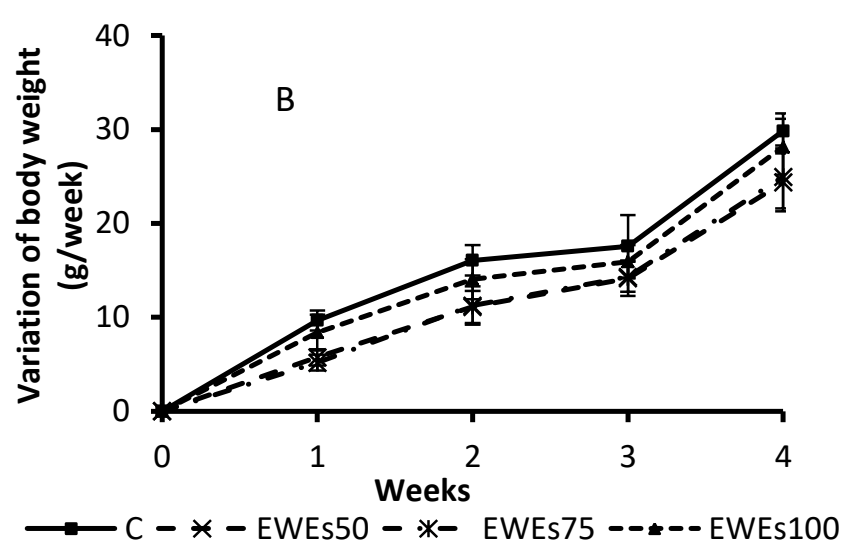

Figure 1. Variation in mean body weight of males (A) and females (B) in a 28-day subchronic toxicity study in rats treated with ethanol/water extract of E. scordifolia $50 \mathrm{mg} / \mathrm{kg}$ (EWEs50), $75 \mathrm{mg} / \mathrm{kg}$ (EWEs75) and $100 \mathrm{mg} / \mathrm{kg}$ (EWEs100). Data are the means \pm standard error of the mean, $\mathrm{n}=5$ in each group. Significant differences: ${ }^{*} \mathrm{p}<0.05, * * \mathrm{P}<0.01$ as compared with the controls at the same week.

\section{Effect of Ethanol/Water Extract of E. scordifolia on Average Feed and Water Consumption}

Food intake during the four weeks of treatment increased in all animals from the beginning of treatment. This food intake in all treated group was significantly lower $(\mathrm{P}<0.01)$ compared to the control group. The water intake in the second, third and fourth week of treatment have decreased compared to the first week of treatment in all animals (Table 2).

Table 2. Food (g/day) and water (mL/day) intake in male and female rats in a 28-day subchronic toxicity study of ethanol/water extract of Euphorbia scordifolia $(\mathrm{n}=5)$.

\begin{tabular}{|c|c|c|c|c|c|c|}
\hline & & Dose (mg/kg) & W1 & W2 & W3 & W4 \\
\hline \multirow[t]{8}{*}{ Male } & \multirow{4}{*}{$\begin{array}{l}\text { Food intake } \\
\text { (g/day) }\end{array}$} & 0 & $26.99 \pm 1.43$ & $25.91 \pm 1.50$ & $30.03 \pm 1.20^{* *}$ & $29.90 \pm 1.52^{* *}$ \\
\hline & & 50 & $21.48 \pm 1.09^{\mathrm{b}}$ & $23.11 \pm 0.94^{\mathrm{a}}$ & $26.13 \pm 1.00 * * b$ & $26.45 \pm 0.99 * * \mathrm{~b}$ \\
\hline & & 75 & $23.02 \pm 1.59^{\mathrm{a}}$ & $24.23 \pm 1.46$ & $26.33 \pm 0.85^{* \mathrm{~b}}$ & $27.59 \pm 1.29^{* * a}$ \\
\hline & & 100 & $23.17 \pm 1.38^{\mathrm{a}}$ & $23.95 \pm 1.56$ & $25.76 \pm 1.81^{* \mathrm{~b}}$ & $29.21 \pm 1.81^{* *}$ \\
\hline & \multirow{4}{*}{$\begin{array}{l}\text { Water intake } \\
\text { (mL/day) }\end{array}$} & 0 & $21.67 \pm 0.60$ & $21.86 \pm 0.49$ & $20.56 \pm 0.76$ & $19.80 \pm 0.69$ \\
\hline & & 50 & $19.56 \pm 0.37$ & $19.06 \pm 0.24^{\mathrm{a}}$ & $19.17 \pm 0.30$ & $19.04 \pm 0.39$ \\
\hline & & 75 & $20.49 \pm 0.98$ & $19.37 \pm 0.95$ & $19.91 \pm 0.50$ & $19.97 \pm 0.66$ \\
\hline & & 100 & $21.91 \pm 1.58$ & $17.89 \pm 1.43^{* * \mathrm{~b}}$ & $17.60 \pm 0.56^{* * \mathrm{~b}}$ & $16.34 \pm 0.57^{* * \mathrm{~b}}$ \\
\hline \multirow[t]{8}{*}{ Female } & \multirow{4}{*}{$\begin{array}{l}\text { Food intake } \\
\text { (g/day) }\end{array}$} & 0 & $22.78 \pm 1.68$ & $24.21 \pm 0.85$ & $27.43 \pm 1.32$ & $26.21 \pm 1.58$ \\
\hline & & 50 & $20.52 \pm 0.11$ & $21.73 \pm 0.84^{\mathrm{a}}$ & $24.75 \pm 0.75^{\mathrm{a}}$ & $24.39 \pm 0.45$ \\
\hline & & 75 & $21.07 \pm 0.91$ & $22.89 \pm 1.25$ & $24.89 \pm 1.09^{\mathrm{a}}$ & $24.23 \pm 1.04$ \\
\hline & & 100 & $21.30 \pm 1.69$ & $22.32 \pm 0.78$ & $26.03 \pm 1.21$ & $22.91 \pm 1.00^{\mathrm{b}}$ \\
\hline & \multirow{4}{*}{$\begin{array}{l}\text { Water intake } \\
\text { (mL/day) }\end{array}$} & 0 & $20.11 \pm 0.62$ & $18.54 \pm 0.56$ & $18.60 \pm 0.34$ & $18.49 \pm 0.24$ \\
\hline & & 50 & $17.31 \pm 0.47^{\mathrm{a}}$ & $17.69 \pm 0.39$ & $17.83 \pm 0.41$ & $18.60 \pm 0.41$ \\
\hline & & 75 & $18.14 \pm 0.35$ & $18.23 \pm 0.31$ & $19.54 \pm 0.35$ & $19.23 \pm 0.32$ \\
\hline & & 100 & $21.46 \pm 0.25$ & $18.80 \pm 0.68^{*}$ & $19.26 \pm 0.40^{*}$ & $15.86 \pm 0.47 * *$ \\
\hline
\end{tabular}

Data are the means \pm standard error of the mean, $\mathrm{n}=5$ in each group. Significant differences: ${ }^{*} \mathrm{p}<0.05, * * \mathrm{P}<0.01$ as compared with the first week of treatment; ${ }^{\mathrm{a}} \mathrm{p}<0.05,{ }^{\mathrm{b}} \mathrm{P}<0.01$ as compared with the controls at the same week (W).

\section{Relative Organ Weight}

After four weeks of treatment with ethanol/water extract of E. scordifolia, the relative organ weight in all treated female rats such as liver, kidney, lung, heart and spleen did not change significantly compared to the control group rat, while all treated male rats liver and spleen relative weight were significant decrease $(\mathrm{P}<0.05$ and $\mathrm{P}<0.01$ respectively) (Table 3 ). 
Table 3. Relative organ weight (\%) of liver, kidney, lung, heart and spleen in male and female rats treated with ethanol/water extract of E. scordifolia for four weeks.

\begin{tabular}{ccccccc}
\hline & Dose (mg/kg) & Liver (\%) & Heart (\%) & Kidney (\%) & Spleen (\%) & Lung (\%) \\
\hline Male & 0 & $3.21 \pm 0.35$ & $0.31 \pm 0.01$ & $0.65 \pm 0.03$ & $0.33 \pm 0.03$ & $0.69 \pm 0.07$ \\
& 50 & $2.49 \pm 0.02 *$ & $0.33 \pm 0.03$ & $0.63 \pm 0.01$ & $0.23 \pm 0.02 * *$ & $0.62 \pm 0.02$ \\
& 75 & $2.65 \pm 0.04 *$ & $0.33 \pm 0.02$ & $0.64 \pm 0.02$ & $0.25 \pm 0.01 * *$ & $0.80 \pm 0.04$ \\
& 100 & $2.65 \pm 0.06 *$ & $0.34 \pm 0.02$ & $0.63 \pm 0.02$ & $0.26 \pm 0.02 * *$ & $0.79 \pm 0.05$ \\
\hline Female & 0 & $2.80 \pm 0.15$ & $0.34 \pm 0.03$ & $0.66 \pm 0.02$ & $0.28 \pm 0.02$ & $0.70 \pm 0.08$ \\
& 50 & $2.63 \pm 0.08$ & $0.33 \pm 0.01$ & $0.63 \pm 0.01$ & $0.29 \pm 0.01$ & $0.78 \pm 0.05$ \\
& 75 & $2.79 \pm 0.11$ & $0.37 \pm 0.01$ & $0.71 \pm 0.01$ & $0.27 \pm 0.02$ & $0.87 \pm 0.07$ \\
& 100 & $2.68 \pm 0.11$ & $0.38 \pm 0.01$ & $0.68 \pm 0.02$ & $0.27 \pm 0.02$ & $0.87 \pm 0.07$
\end{tabular}

Data are the means \pm standard error of the mean, $\mathrm{n}=5$ in each group. Significant differences: ${ }^{*} \mathrm{p}<0.05,{ }^{*} \mathrm{P}<0.01$ as compared with control group

\section{Effect of Ethanol/Water Extract of E. scordifolia on Stool and Urine Emission}

The stools are molded in all animals over four weeks of treatment. In all treated animals, the quality and quantity of stools did not change significantly during the 28 days of treatment with ethanol/water extract of $E$. scordifolia. No significant difference $(\mathrm{P}>0.05)$ was observed in urinary volume of all treated groups with ethanol/water extract of E. scordifolia (Table 4).

Table 4. Issue of stool and urine in male and in female in a 28-day subchronic toxicity study of ethanol/water extract of $E$. scordifolia (EWEs) in rats.

\begin{tabular}{ccccccc}
\hline & Dose (mg/kg) & W1 & W2 & W3 & W4 \\
\hline \multirow{4}{*}{ Male } & 0 & $10.75 \pm 0.50$ & $10.46 \pm 1.10$ & $11.19 \pm 1.35$ & $10.44 \pm 1.21$ \\
& & 50 & $9.09 \pm 0.84$ & $9.79 \pm 1.10$ & $9.15 \pm 0.93$ & $8.55 \pm 0.82$ \\
& & 75 & $10.37 \pm 0.51$ & $10.53 \pm 0.48$ & $9.50 \pm 0.53$ & $10.50 \pm 1.08$ \\
& & 100 & $10.51 \pm 1.00$ & $11.19 \pm 1.24$ & $8.36 \pm 0.98$ & $10.79 \pm 1.78$ \\
\cline { 3 - 7 } & & 0 & $13.40 \pm 0.78$ & $12.03 \pm 0.60$ & $12.66 \pm 0.69$ & $13.51 \pm 0.83$ \\
& & 50 & $12.37 \pm 0.63$ & $11.17 \pm 0.92$ & $12.69 \pm 0.82$ & $14.97 \pm 0.84$ \\
& & 75 & $12.26 \pm 0.60$ & $12.46 \pm 0.84$ & $13.66 \pm 0.42$ & $14.17 \pm 0.65$ \\
& & 100 & $13.40 \pm 0.70$ & $13.60 \pm 0.72$ & $14.80 \pm 0.65$ & $17.80 \pm 0.34$ \\
\hline \multirow{4}{*}{ Female (mL/day) } & 0 & $10.24 \pm 0.70$ & $10.28 \pm 0.82$ & $9.58 \pm 0.46$ & $10.02 \pm 0.81$ \\
& & 50 & $9.96 \pm 0.26$ & $9.44 \pm 0.70$ & $9.92 \pm 0.46$ & $9.48 \pm 0.28$ \\
& & 75 & $10.75 \pm 0.28$ & $10.58 \pm 0.40$ & $11.10 \pm 0.37$ & $10.35 \pm 0.49$ \\
& & 100 & $10.84 \pm 0.30$ & $10.58 \pm 0.66$ & $10.81 \pm 0.52$ & $9.78 \pm 0.28$ \\
\cline { 3 - 7 } & & 0 & $10.97 \pm 0.75$ & $10.71 \pm 0.78$ & $10.79 \pm 0.41$ & $13.80 \pm 0.86$ \\
& & 50 & $9.46 \pm 0.47$ & $8.89 \pm 0.74$ & $10.21 \pm 0.49$ & $12.26 \pm 0.31$ \\
& & 75 & $10.60 \pm 0.80$ & $11.20 \pm 0.94$ & $12.66 \pm 0.86$ & $14.29 \pm 0.82$ \\
& & 100 & $12.43 \pm 0.70$ & $10.97 \pm 0.62$ & $15.69 \pm 0.38$ & $16.29 \pm 0.63$
\end{tabular}

Data are the means \pm standard error of the mean, $n=5$ rats in each group. Week (W)

\section{Biochemistry Parameters}

The serum creatinine concentration, the urinary creatinine concentration, serum-to-urine creatinine ratio, total protein concentration and alanine aminotransferase (ALAT) in all treated female and male rats did not change significantly compared to the control group (Table 5). 
Table 5. Serum creatinine concentration (SCC), urinary creatinine concentration (UCC), serum-tourine creatinine ratio (SCC/UCC), total protein concentration and alanine aminotransferase (ALT) levels in male and female rats after four weeks of treatment with ethanol/water extract of $E$. scordifolia (EWEs).

\begin{tabular}{ccccccc}
\hline & Dose $\mathbf{( m g} / \mathbf{k g})$ & {$[\mathbf{U C C}](\mathbf{m g} / \mathbf{L})$} & {$[\mathbf{S C C}] \mathbf{( m g / L )}$} & UCC/SCC & Proteins $\mathbf{( g / L})$ & $[\mathbf{A L A T}] \mathbf{( U / L})$ \\
\hline \multirow{4}{*}{ Male } & $\mathbf{0}$ & $1751.00 \pm 2.96$ & $8.43 \pm 0.30$ & $208.65 \pm 7.25$ & $18.54 \pm 0.42$ & $38.50 \pm 0.61$ \\
& $\mathbf{5 0}$ & $1749.67 \pm 1.78$ & $8.30 \pm 0.18$ & $211.17 \pm 4.30$ & $18.08 \pm 0.22$ & $38.50 \pm 0.61$ \\
& $\mathbf{7 5}$ & $1750.67 \pm 2.21$ & $8.40 \pm 0.22$ & $208.95 \pm 5.10$ & $18.57 \pm 0.18$ & $39.14 \pm 0.61$ \\
& $\mathbf{1 0 0}$ & $1749.33 \pm 4.37$ & $8.27 \pm 0.44$ & $213.93 \pm 11.00$ & $18.82 \pm 0.16$ & $39.79 \pm 0.82$ \\
\hline \multirow{4}{*}{ Female } & $\mathbf{0}$ & $1730.00 \pm 1.58$ & $6.33 \pm 0.16$ & $273.83 \pm 6.72$ & $17.92 \pm 0.54$ & $40.11 \pm 0.61$ \\
& $\mathbf{5 0}$ & $1729.00 \pm 1.55$ & $6.23 \pm 0.15$ & $278.07 \pm 7.00$ & $17.70 \pm 0.20$ & $41.08 \pm 0.40$ \\
& $\mathbf{7 5}$ & $1734.00 \pm 2.56$ & $6.73 \pm 0.26$ & $258.92 \pm 9.21$ & $17.54 \pm 0.18$ & $40.44 \pm 0.72$ \\
& $\mathbf{1 0 0}$ & $1732.00 \pm 2.95$ & $6.53 \pm 0.30$ & $267.29 \pm 12.11$ & $18.35 \pm 0.18$ & $41.73 \pm 0.94$ \\
\hline
\end{tabular}

Data are the means \pm standard error of the mean, $n=5$ rats in each group. No significant difference

\section{Hematological Parameters}

In treated male rats with ethanol/water extract of E. scordifolia at dose $100 \mathrm{mg} / \mathrm{kg} \mathrm{bw}$, total white blood cells count were decreased significantly $\left(4.99 \pm 0.16 \times 10^{3} / \mathrm{mm}^{3} ; \mathrm{P}<0.01\right)$ compared to the control group $\left(10.40 \pm 0.40 \times 10^{3} / \mathrm{mm}^{3}\right)$. Other parameters such as red blood cells, hemoglobin, hematocrit, and platelets, $\mathrm{MCV}, \mathrm{MCH}$ and $\mathrm{MCHC}$ values did not change significantly in treated male rats. In female rats, total white blood cell count decreased significantly in those treated with EWEs100 $\left(5.44 \pm 0.21 \times 10^{3} / \mathrm{mm}^{3} ; \mathrm{P}<0.01\right)$ compared with normal rats $\left(7.73 \pm 0.32 \times 10^{3} / \mathrm{mm}^{3}\right)$. The red blood cell count $(\mathrm{P}<0.05)$, the hemoglobin $(\mathrm{P}<0.01)$ and hematocrit $(\mathrm{P}<0.01)$ were decreased significantly in all treatment groups. Platelet counts were increased significantly in female rats treated with EWEs75 $\left(8.09 \pm 0.08 \times 10^{5} / \mathrm{mm}^{3} ; \mathrm{P}<0.05\right)$ and EWEs100 $\left(8.09 \pm 0.14 \times 10^{5} / \mathrm{mm}^{3}\right.$; $\mathrm{P}<0.05)$ compared with normal rats $\left(6.69 \pm 0.73 \times 10^{5} / \mathrm{mm}^{3}\right) . \mathrm{MCV}, \mathrm{MCH}$ and $\mathrm{MCHC}$ values did not change significantly in treated female rats (Table 6).

Table 6. Hematologic means parameters in male and females rats after four weeks of treatment with ethanol/water extract of E. scordifolia50 mg / kg (EWEs50), $75 \mathrm{mg} / \mathrm{kg}$ (EWEs75) and $100 \mathrm{mg} / \mathrm{kg}$ (EWEs100).

\begin{tabular}{llcccc}
\hline & Parameters & Control & EWEs50 & EWEs75 & EWEs100 \\
\hline \multirow{6}{*}{ Male } & $\mathrm{WBC} \times 10^{3} / \mathrm{mm}^{3}$ & $10.40 \pm 0.40$ & $10.52 \pm 0.21$ & $9.99 \pm 0.16$ & $4.99 \pm 0.16^{* *}$ \\
& $\mathrm{RBC} \times 10^{6} / \mathrm{mm}^{3}$ & $8.04 \pm 0.34$ & $7.76 \pm 0.21$ & $8.26 \pm 0.14$ & $7.28 \pm 0.09$ \\
& $\mathrm{Hb}(\mathrm{g} / \mathrm{dL})$ & $17.65 \pm 0.73$ & $18.70 \pm 0.33$ & $17.96 \pm 0.19$ & $15.96 \pm 0.19$ \\
& $\mathrm{Ht}(\%)$ & $49.65 \pm 2.40$ & $50.48 \pm 0.64$ & $48.78 \pm 0.56$ & $45.79 \pm 0.56$ \\
& $\mathrm{PC} \times 10^{5} / \mathrm{mm}^{3}$ & $8.46 \pm 0.54$ & $9.42 \pm 0.20$ & $8.62 \pm 0.14$ & $8.62 \pm 0.31$ \\
& $\mathrm{MCV}\left(\mu \mathrm{m}^{3}\right)$ & $61.72 \pm 1.23$ & $65.18 \pm 1.38$ & $59.10 \pm 0.77$ & $62.89 \pm 0.09$ \\
& $\mathrm{MCH}(\rho \mathrm{g})$ & $21.95 \pm 0.04$ & $24.16 \pm 0.66$ & $21.76 \pm 0.28$ & $21.92 \pm 0.03$ \\
& $\mathrm{MCHC}\left(\rho \mathrm{g} / \mathrm{dL}^{3}\right)$ & $35.63 \pm 0.76$ & $37.05 \pm 0.44$ & $36.81 \pm 0.02$ & $34.85 \pm 0.01$ \\
\hline \multirow{6}{*}{ Female } & $\mathrm{WBC} \times 10^{3} / \mathrm{mm}^{3}$ & $7.73 \pm 0.32$ & $7.14 \pm 0.18$ & $7.44 \pm 0.21$ & $5.44 \pm 0.21^{* *}$ \\
& $\mathrm{RBC} \times 10^{6} / \mathrm{mm}^{3}$ & $9.56 \pm 0.69$ & $7.42 \pm 0.24^{*}$ & $8.00 \pm 0.24 *$ & $7.20 \pm 039^{*}$ \\
& $\mathrm{Hb}(\mathrm{g} / \mathrm{dL})$ & $20.97 \pm 1.51$ & $16.13 \pm 0.17^{* *}$ & $16.76 \pm 0.22^{* *}$ & $15.76 \pm 0.85^{* *}$ \\
$\mathrm{HC} \times 10^{5} / \mathrm{mm}^{3}$ & $60.07 \pm 4.31$ & $50.61 \pm 0.92^{* *}$ & $50.84 \pm 0.26^{* *}$ & $45.24 \pm 2.44^{* *}$ \\
$\mathrm{MCV}\left(\mu \mathrm{m}^{3}\right)$ & $62.86 \pm 0.73$ & $7.67 \pm 0.33$ & $8.09 \pm 0.08^{*}$ & $8.09 \pm 0.14^{*}$ \\
$\mathrm{MCH}(\rho \mathrm{gg})$ & $21.94 \pm 0.02$ & $21.86 \pm 0.95$ & $21.01 \pm 0.44$ & $21.90 \pm 0.06$ \\
$\mathrm{MCHC}(\rho \mathrm{g} / \mathrm{dL})$ & $34.90 \pm 0.05$ & $31.89 \pm 0.42$ & $32.98 \pm 0.52$ & $34.85 \pm 0.01$ \\
\hline
\end{tabular}

Data are the means \pm standard error of the mean. Significant differences: ${ }^{*} \mathrm{p}<0.05,{ }^{*} \mathrm{P}<0.01$ as compared with the control group $(\mathrm{n}=5)$. WBC: white blood cells. Hb: hemoglobin. Ht: hematocrit. RBC: red blood cells. PC: blood platelets. MCV: mean corpuscular volume. MCH: mean corpuscular hemoglobin. MCHC: mean corpuscular hemoglobin concentration. 


\section{Histopathological Examination}

The results of histopathological examination of liver section in rats treated with ethanol/water extract and control group rats are shown in Fig. 2. The liver in control group rats presented the normal hepatic architecture with sinusoids and hepatocytes (Fig. 2A). For the rats administered with 50 and $75 \mathrm{mg} / \mathrm{kg}$ body weight of ethanol/water extract of E. scordifolia, there was mild hepatic steatosis (Fig. 2B and 2C), while $100 \mathrm{mg} / \mathrm{kg}$ body weight of ethanol/water extract of E. scordifolia treated rats showed moderate necrosis of hepatocytes and central vein (Fig. 2D).
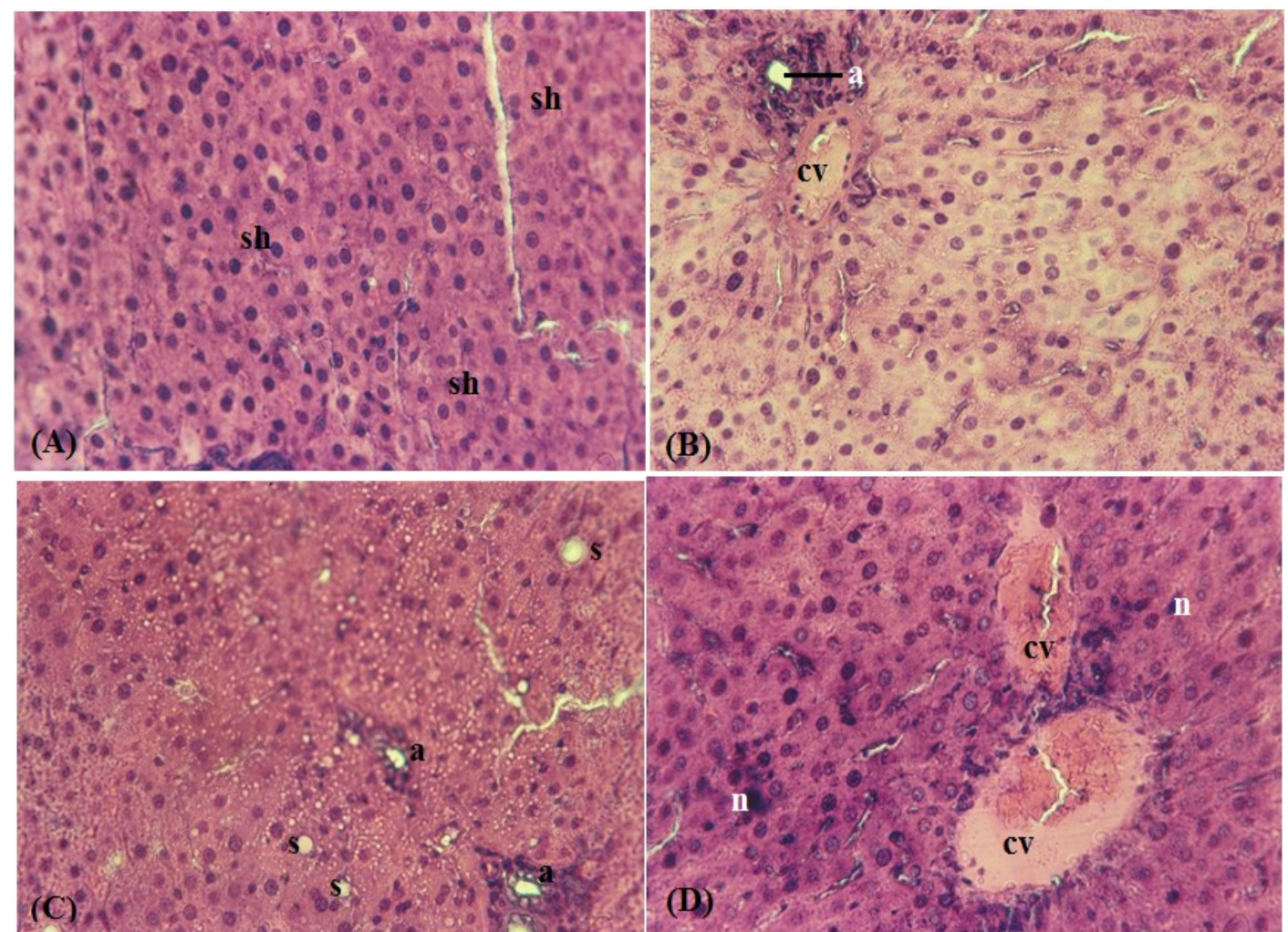

(H\&E, 400)

Figure 2. Liver sections stained with hematoxylin and eosin showing the effect of Euphorbia scordifolia ethanol/water extract (EWEs) in a 28-day subchronic toxicity study in rats: (a) Control group; (b) $50 \mathrm{mg} / \mathrm{kg}$; (c) $75 \mathrm{mg} / \mathrm{kg}$ and (d) $100 \mathrm{mg} / \mathrm{kg}$. Indicators: Artery (a); Central Vein (CV); Necrosis (n); steatosis (s); sinusoid and hepatocyte (sh).

The kidney in control group rats and treated rats with $50 \mathrm{mg} / \mathrm{kg}$ body weight of ethanol/water extract of E. scordifolia presented the intact glomeruli, Malpighi corpuscles and tubules (Fig. 3A and $3 \mathrm{~B}$ ). The kidney in treated rats with $75 \mathrm{mg} / \mathrm{kg}$ body weight of ethanol/water extract of $E$. scordifolia presented normal glomeruli, Malpighi corpuscles, tubules and blood vessels (Fig. 3C). The clarification of renal structure was presented in rats treated with $100 \mathrm{mg} / \mathrm{kg}$ body weight of ethanol/water extract of E. scordifolia (Fig. 3D). 

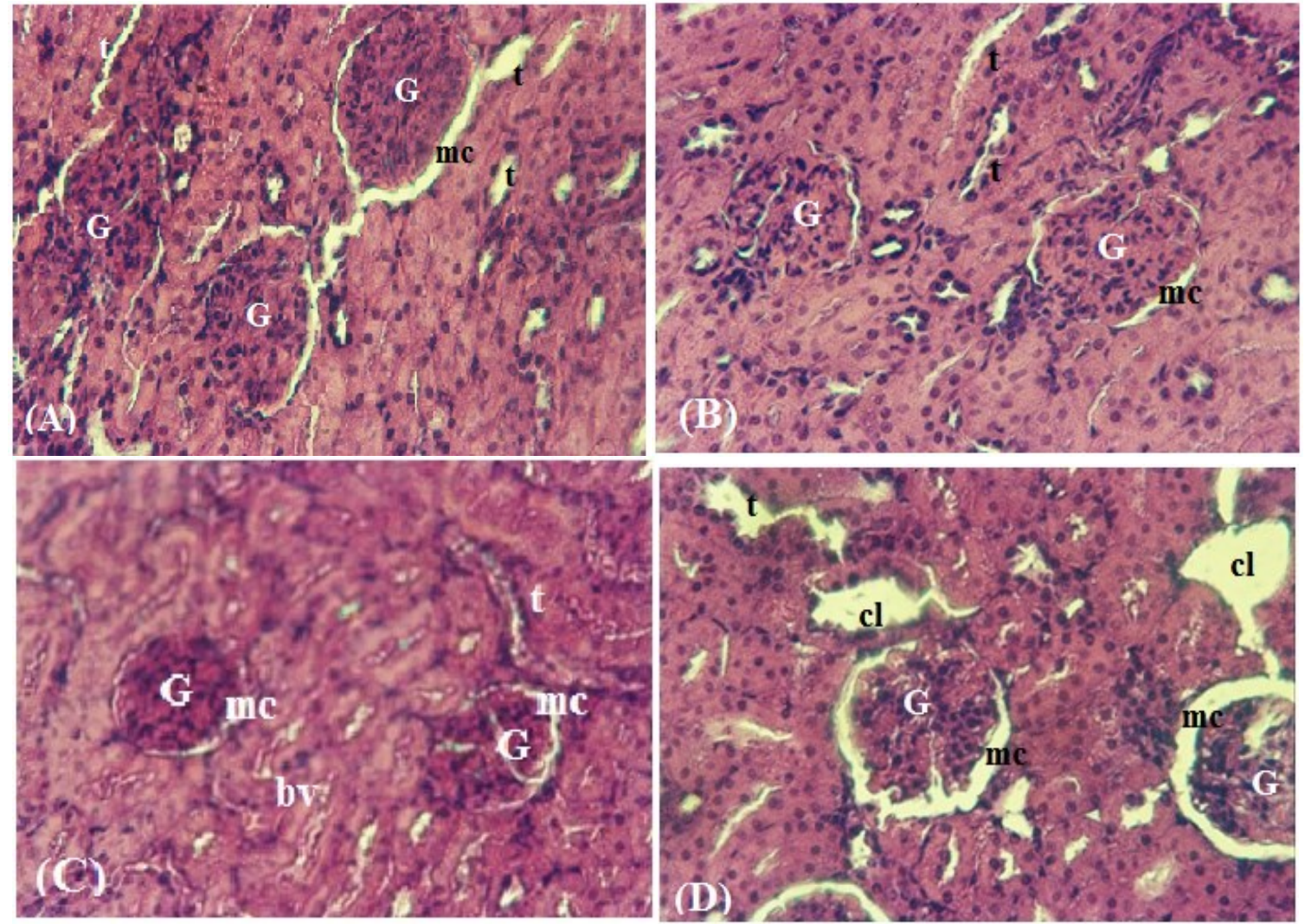

$(\mathrm{H} \& \mathrm{E}, 400)$

Figure 3. Kidney sections stained with hematoxylin and eosin showing the effect of Euphorbia scordifolia ethanol/water extract (EWEs) in a 28-day subchronic toxicity study in rats: (a) Control group; (b) $50 \mathrm{mg} / \mathrm{kg}$; (c) $75 \mathrm{mg} / \mathrm{kg}$ and (d) $100 \mathrm{mg} / \mathrm{kg}$. Indicators: clarification of renal structure (cl); Malpighi corpuscles (mc); glomeruli (G); tubules (t); blood vessels (bv).

The results of histopathological examination of the spleen section in rats treated with ethanol/water extract and control group rats are shown in Fig. 4. The spleen in control group rats and treated rats with $50 \mathrm{mg} / \mathrm{kg}$ body weight of ethanol/water extract of E. scordifolia presented the normal red pulp, white pulp and central artery (Fig. 4A and 4B). For the rats administered with 75 and $100 \mathrm{mg} / \mathrm{kg}$ body weight of ethanol/water extract of E. scordifolia, histopathological examination of the spleen section presented a proliferation of lymphocytes in the white pulp with a substantial presence of connective fibers of the red pulp and central artery (Fig. 4C and 4D).
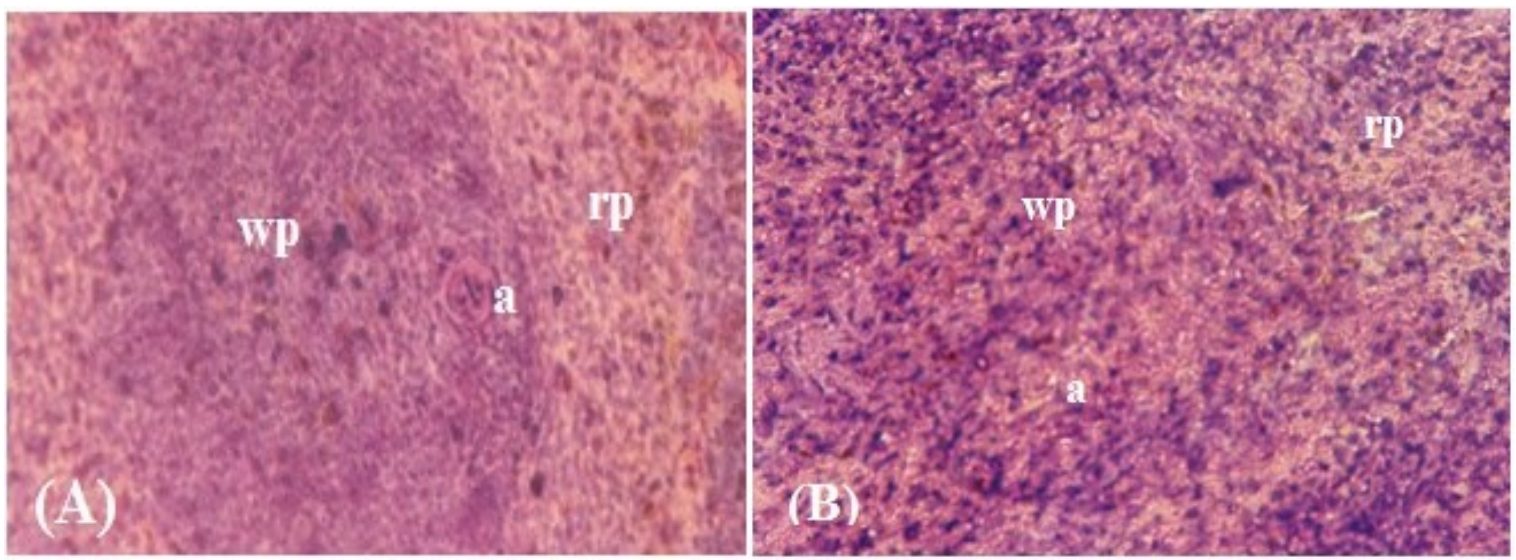

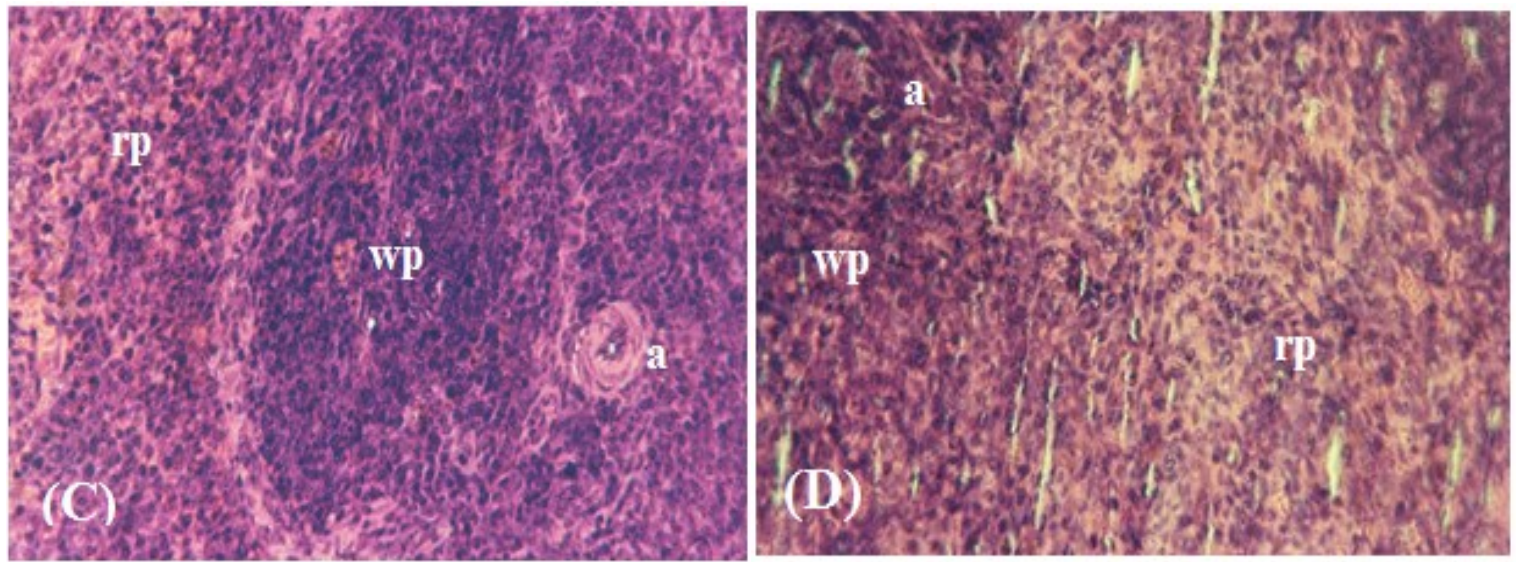

(H\&E, 400)

Figure 4. Spleen sections stained with hematoxylin and eosin showing the effect of Euphorbia scordifolia ethanol/water extract (EWEs) in a 28-day subchronic toxicity study in rats: (A) Control group; (B) $50 \mathrm{mg} / \mathrm{kg}$; (C) $75 \mathrm{mg} / \mathrm{kg}$ and (D) $100 \mathrm{mg} / \mathrm{kg}$. Indicators: artery (a); red pulp (rp); white pulp (wp).

\section{Discussion}

The strategy for establishment of safety of a test item depends on demonstration of its adverse effects or no adverse effects under the conditions of exposure to its high doses to the test animals [17]. Toxicology can be defined as that branch of science that deals with poisons, and a poison can be defined as any substance that causes a harmful effect when administered, either by accident or design, to a living organism [18]. According to the Guidance Document on Acute Oral Toxicity Testing based on oral LD50 value which were recommended by Organization for Economic Cooperation and Development [11], the crude extracts of E. scordifolia may be assigned to be class 5 (LD50>5000 mg/kg body weight), which was designated to be the lowest toxicity class.

In the sub-chronic studies, the extract did not appear to affect the normal growth of animals as evidenced by comparable weight variation by both control and test animals over the four weeks treatment period. Furthermore, there was no significant change in relative organs weight such as kidney, liver, lung and spleen in treated animals compared to control animals. Relative weight is more indicative of toxicity than absolute weight [19]. The oral administration of multiple doses of the ethanol/ water extract of E. scordifolia resulted in no deaths. In all treated male rats, we noticed a decrease change in variation body weight $(\mathrm{P}<0.05)$ compared to control, certainly related to the decline in food and water intake in these animals [20] or could be explained by the presence of antinutritional molecules such as tannins [21]. This variation in body weight was small and not significant in female rats. The decline in the stools emission in all treated animals would be correlated with the presence of anti-diarrheal compounds and antimotility such as saponins, terpenes, phenols, anthraquinones and anthocyanidins [22] in our extract, or could be due to the decline in food intake which it would be due to the anti-nutritional compounds such as tannins [21]. Assessment of liver and kidney function is a very vital index in evaluating the toxicity of drugs and plant extracts. Liver function indices evaluated in this study were alanine aminotransferase concentrations, total protein levels and histological structure. The rate of alanine aminotransferase and the total protein levels remain normal in all treated animals, showing that the function of the liver in detoxification remained effective. These results are explained by the absence or low rate of hepatocyte necrosis [23] and a balance between synthesis and degradation of proteins in the body [24]. Kidney function indices evaluated in this study were creatinine concentrations and histological structure. Serum creatinine concentration, urinary creatinine concentration, and serum-to-urine creatinine ratio were normal in all treated animals, but relatively lower in females compared to males. This difference between males and females would be linked to the more muscle mass in males [25]. These extracts do not affect renal function, but increase urination (urinary excretion) 
probably tubular dilation. Male and female rats treated with $100 \mathrm{mg} / \mathrm{kg}$ body weight showed a significant decrease $(\mathrm{P}<0.01)$ in white blood cells compared to the control. The other haematological parameters remained normal in males. In females, red blood cells, hemoglobin and hematocrit decreased significantly $(\mathrm{P}<0.01)$ in all treated groups. In animals treated with the $75 \mathrm{mg} / \mathrm{kg}$ dose, lymphocyte proliferation was observed in the white pulp of the spleen. These results could be explained by the presence of toxic compounds such as saponines that cause hemolysis [1] and/or immunostimulator compounds such as terpene [26] in our extract.

\section{Conclusion}

Oral acute toxicity of the ethanol/water extract of E. scordifolia Jacq in rodents is low (oral LD50> $5000 \mathrm{mg} / \mathrm{kg}$ ). However, in the sub-chronic study, haematological studies showed a significant decrease in white blood cells and red blood cells in males treated with $100 \mathrm{mg} / \mathrm{kg}$ body weight and a significant decrease in hemoglobin, hematocrit in all treated females. It would be necessary to use the ethanol/water extract for short periods ( $<4$ weeks). Thus, the plant, at least its ethanol/water extract, could be considered with a wide margin of safety for short-term oral use.

\section{Competing Interests}

The authors declare that there is no conflict of interests.

\section{Acknowledgement}

The authors wish to thank the Institute of Medical Research and Medicinal Plants studies (IMPM) of Yaoundé Cameroon for the financial support.

\section{References}

[1] J. Westendorf, Natural compounds, in: H. Marquardt et al. (Eds.), Toxicology, Elsevier Inc., 1999, pp. 959-1007.

[2] B. Bremer et al., An update of the Angiosperm Phylogeny Group classification for the orders and families of flowering plants : APG III, Bot. J. Linn. Soc. 161 (2009) 105-121.

[3] A. Naegelé, Contributions à l'étude de la flore et des groupements végétaux de la Mauritanie, Bulletin Institut Fondamental d'Afrique Noire. A (1958) 293-305.

[4] A.O.M.Vall Hmeyada, Contribution à l'étude des plantes médicinales de Mauritanie, Ann. Univ. Lomé (Togo), Série Sci. 17 (2009) 9-27.

[5] H.M. Burkill, The useful plants of west tropical Africa, R. Bot. Gard. Kew. 2 (1985).

[6] R. Kamgang et al., Activity of aqueous ethanol extract of Euphorbia scordifolia on Shigella dysenteriae type 1-induced diarrhea in rats, Int. J. Pharm. Sci. Drug Res. 7 (2015) 40-45.

[7] O.O. Odebiyi, E.A. Sofowora, Phytochemical screening of Nigerian medicinal plants II., Lloydia J. Nat. Prod. 41 (1991) 234-246.

[8] R. Kamgang et al., Antihyperglycaemic potential of the water-ethanol extract of Kalanchoe crenata (Crassulaceae), J. Nat. Med. 62(1) (2008) 34-40.

[9] J. Smith et al., Principles and practice in ethical review of animal experiments across Europe: summary of the report of a FELASA working group on ethical evaluation of animal experiments, Laboratory Animals. 41(2) (2007) 143-160.

[10] OECD/OCDE, Test Guideline 452: Chronic Toxicity Studies, Draft Consult. Propos. 8 (2008) 1-15. 
[11] OECD/OCDE, Acute Oral Toxicity - Up-and-Down-Procedure (UDP), OECD Guideline for the Testing of Chemicals. 425 (2008) 1-27.

[12] S.C. Gad, C.P. Chengelis, Introduction, in: S.C. Gad, C.P. Chengelis (Eds.), Acute Toxicology Testing(Second edition), Elsevier Inc., 1998, pp. 1-15.

[13] GS.C. Gad, C.P. Chengelis, Acute toxicology program : study design and development, in: S.C. Gad, C.P. Chengelis (Eds.), Acute Toxicology Testing(Second edition), Elsevier Inc., 1998, pp. 17-30.

[14] C.J. Chang et al., Acute and 28-day subchronic oral toxicity of an ethanol extract of Zingiber zerumbet (L.) Smith in rodents, Evidence-Based Complementary and Alternative Medicine. 2012 (2012) 1-11.

[15] A.G. Gornall, C.J. Bardawill, M.M. David, determination of serum proteins by means of the biuret reaction, J. Biol. Chem. 177 (1949) 751-766.

[16] V. Marck, Anatomie et cytologie pathologiques, in: V. Marck (Ed.), Manuel de techniques d'anatomo-cytopathologie, Masson SAS, Elsevier, Paris, 2010, pp. 35-132. doi:10.1016/B978-2-294-70844-2.00003-4.

[17] S.A. Dar et al., Acute and Sub-acute oral toxicity studies of Deedan-A Unani drug in Albino rats, J. Appl. Pharm. Sci. 5 (2015) 107-114.

[18] E. Hodgson, Introduction to toxicology, in: E. Hodgson(Ed.), A Textbook of Modern Toxicology(Third Edition), A John Wiley \& Sons, Inc., Publication, United States of America, 2004, pp. 1-12.

[19] J. Demma et al., Toxicological study on Glinus lotoides: A traditionally used taenicidal herb in Ethiopia, J. Ethnopharmacol. 111 (2007) 451-457.

[20] M. Case, L. Sibinski, G. Steffen, Chronic oral toxicity and oncogenicity studies of flecaimide, an antirythmic, in rats and mice, Toxicol. Appli. Pharmacol. 73 (1984) 232-242.

[21] P. Besançon, Innocuite et disponibilite des nutriments dans les aliments de complement, in: S. Trèche et al. (Eds.), L'alimentation Complément Du Jeune Enfant, ORSTOM Edi, Amazon France, 1995, pp. 105-121.

[22] S. Meite et al., Antidiarrheal Activity of the ethyl acetate extract of Morinda morindoides in rats, Trop. J. Pharm. Res. 8 (2009) 201-207.

[23] G. Gibson, P. Skett, Introduction to drug metabolism (Second Edition), Blackie Accademic and Professional, London, 1994.

[24] I. Tlak et al., The effect of fasting on the concentrations of total proteins and of uric acid as well as on aminotransferase activity in duckling blood plasma, Vet. Arh. 78 (2008) 377-386.

[25] E. Carole, Estimation de la clairance de la créatinine, Clin. Chem. 27 (2002) 173.

[26] R. Ajaya Kumar et al., Anticancer and immunostimulatory compounds from Andrographis paniculata, J. Ethnopharmacol. 92 (2004) 291-295. 